Prepared in cooperation with the Alabama Department of Transportation

\title{
Magnitude and Frequency of Floods for Urban Streams in Alabama, 2007
}

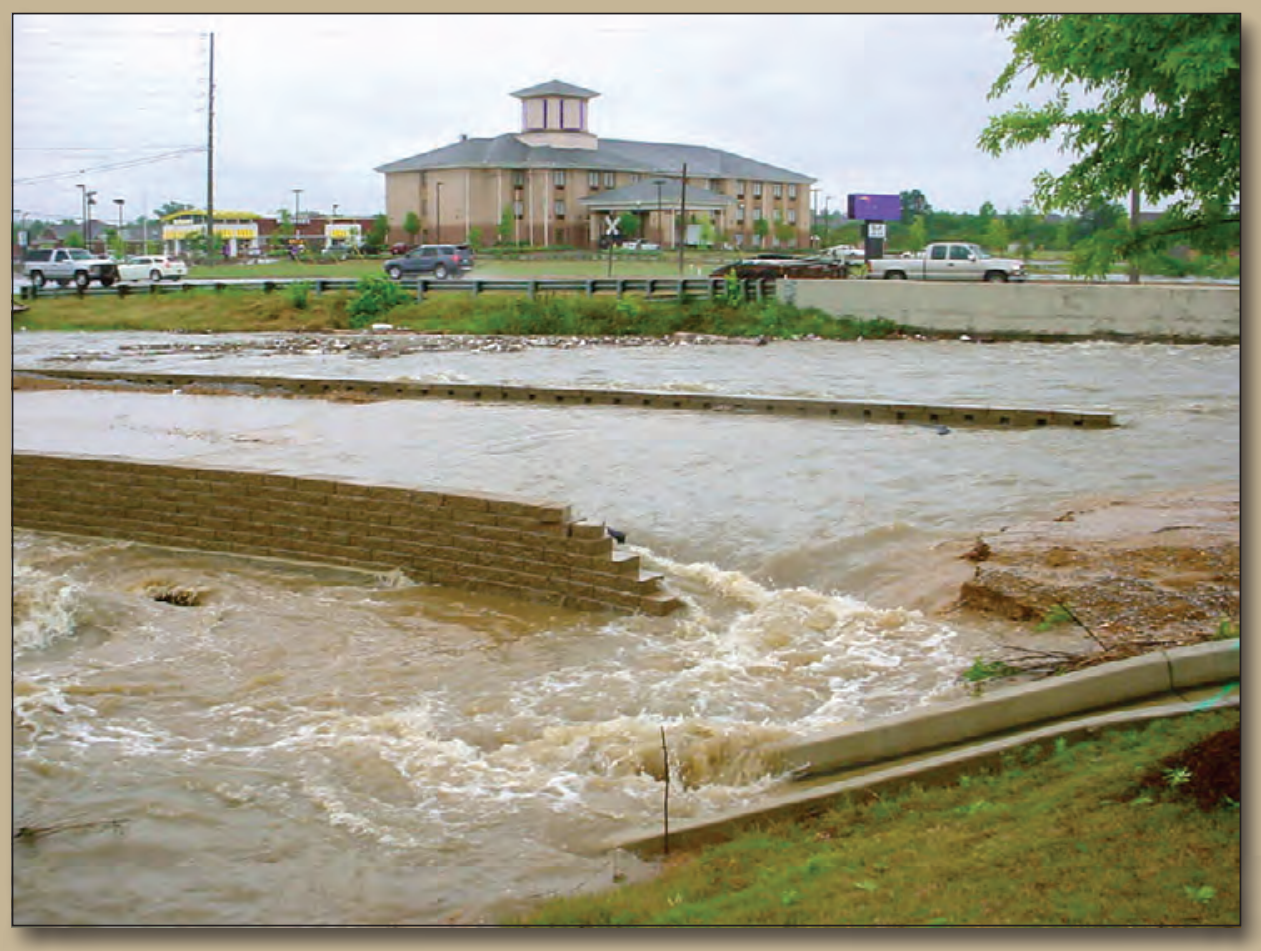

Scientific Investigations Report 2010-5012 
Cover. Flooded tributary to Jenkins Creek at Montgomery, Alabama, May 7, 2009 (photograph taken by T.S. Hedgecock, USGS). 


\section{Magnitude and Frequency of Floods for Urban Streams in Alabama, 2007}

By T.S. Hedgecock and K.G. Lee

Prepared in cooperation with the Alabama Department of Transportation

Scientific Investigations Report 2010-5012 


\title{
U.S. Department of the Interior \\ KEN SALAZAR, Secretary \\ U.S. Geological Survey \\ Marcia K. McNutt, Director
}

\section{U.S. Geological Survey, Reston, Virginia: 2010}

\author{
For more information on the USGS — the Federal source for science about the Earth, its natural and living resources, \\ natural hazards, and the environment, visit http://Www.usgs.gov or call 1-888-ASK-USGS \\ For an overview of USGS information products, including maps, imagery, and publications, \\ visit http://www.usgs.gov/pubprod \\ To order this and other USGS information products, visit http://store.usgs.gov
}

Any use of trade, product, or firm names is for descriptive purposes only and does not imply endorsement by the U.S. Government.

Although this report is in the public domain, permission must be secured from the individual copyright owners to reproduce any copyrighted materials contained within this report.

Suggested citation:

Hedgecock, T.S., and Lee, K.G., 2010, Magnitude and frequency of floods for urban streams in Alabama, 2007: U.S. Geological Survey Scientific Investigations Report 2010-5012, 17 p.

(Also available online at http://pubs.usgs.gov/sir/2010/5012/ 


\section{Contents}

Abstract Introduction
Purpose and Scope
Previous Studies
Description of the Study Area
Flood Data Used in the Analysis
Flood Magnitude and Frequency at Gaging Stations
$\quad$ Urban Flood-Frequency Analysis
$\quad$ Gaged Sites

\section{Figures}

1-2. Maps showing locations of-

1. Physiographic provinces in Alabama...................................................................

2. Cities with urban streamgaging stations that were used in the study .......................

3-5. Maps showing locations of urban streamgaging stations in the vicinity of-

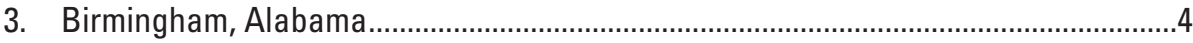

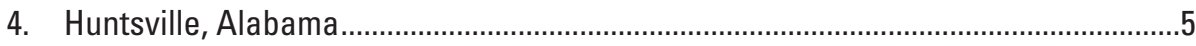

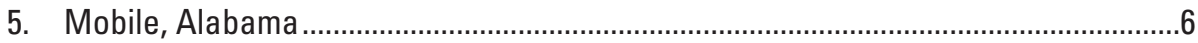

6-8. Maps showing locations of urban streamgaging stations at-

6. Mill Branch at Columbus, Georgia ................................................................................

7. Elevenmile Creek near Pensacola, Florida ..............................................................

8. Gordon Creek at Hattiesburg, Mississippi.................................................................

9. Map showing locations of the four flood regions in Alabama .......................................13

\section{Tables}

1. T-year recurrence intervals with corresponding annual exceedance probabilities and P-percent chance exceedance for flood-frequency flow estimates.........................9

2. Peak flows for selected exceedance probabilities at urban streamgaging stations used in Alabama urban regression analyses.................................................................. 10

3. Regional flood-frequency relations for urban streams in Alabama ...................................12

4. Accuracy of regional flood-frequency relations for urban streams in Alabama.............13

5. Variance of prediction values for urban streamgaging stations used in Alabama urban regression analyses 


\section{Conversion Factors}

\begin{tabular}{lcl}
\multicolumn{1}{c}{ Inch/Pound to SI } & & \\
\hline \multicolumn{1}{c}{ Multiply } & \multicolumn{1}{c}{ By } & \multicolumn{1}{c}{ To obtain } \\
\hline inch (in.) & Length & \\
foot (ft) & 2.54 & centimeter $(\mathrm{cm})$ \\
mile (mi) & 0.3048 & meter $(\mathrm{m})$ \\
& 1.609 & kilometer $(\mathrm{km})$ \\
\hline square mile $\left(\mathrm{mi}^{2}\right)$ & Area & \\
acre & 2.590 & square kilometer $\left(\mathrm{km}^{2}\right)$ \\
& 0.00405 & square kilometer $\left(\mathrm{km}^{2}\right)$ \\
cubic foot per second $\left(\mathrm{ft}^{3} / \mathrm{s}\right)$ & Flow rate & \\
& 0.02832 & cubic meter per second $\left(\mathrm{m}^{3} / \mathrm{s}\right)$ \\
\hline foot per mile $(\mathrm{ft} / \mathrm{mi})$ & Hydraulic gradient & \\
\hline
\end{tabular}

Vertical coordinate information is referenced to the North American Vertical Datum of 1988 (NAVD 88).

Horizontal coordinate information is referenced to the North American Datum of 1983 (NAD 83).

Elevation, as used in this report, refers to distance above the vertical datum. 


\title{
Magnitude and Frequency of Floods for Urban Streams in Alabama, 2007
}

\author{
By T.S. Hedgecock and K.G. Lee
}

\begin{abstract}
Methods of estimating flood magnitudes for exceedance probabilities of 50, 20, 10, 4, 2, 1, 0.5, and 0.2 percent have been developed for urban streams in Alabama that are not significantly affected by dams, flood detention structures, hurricane storm surge, or substantial tidal fluctuations. Regression relations were developed using generalized least-squares regression techniques to estimate flood magnitude and frequency on ungaged streams as a function of the basin drainage area and percentage of basin developed. These methods are based on flood-frequency characteristics for 20 streamgaging stations in Alabama and 3 streamgaging stations in adjacent States having 10 or more years of record through September 2007.
\end{abstract}

\section{Introduction}

The magnitude and frequency of floods are important factors in the design of bridges, culverts, highway embankments, dams, and other structures near streams and rivers. Flood-plain management plans and flood-insurance rates also require information on the magnitude and frequency of floods.

The Alabama Department of Transportation needs accurate flood-frequency information to efficiently design drainage structures in Alabama. To meet this need, the U.S. Geological Survey (USGS), in cooperation with the Alabama Department of Transportation, conducted a study to update previous urban flood-frequency reports on the basis of peak-flow data collected through September 2007 from urban streamgaging stations.

\section{Purpose and Scope}

The information in this report updates previously published urban flood-frequency information for Alabama by providing methods of estimating the magnitude and frequency of floods at ungaged urban streams and provides frequency estimates of peak flow using peak-flow data collected through September 2007 at urban streamgaging stations. Included in this report are equations for estimating the magnitude of floods having exceedance probabilities of 50,20,10,4, 2, 1, 0.5, and 0.2 percent for ungaged and unregulated urban streams and methods for estimating the magnitude and frequency of floods at or near urban gaging stations.

\section{Previous Studies}

Magnitude and frequency of floods in Alabama have been described by Pierce (1954), Speer and Gamble (1964), Gamble (1965), Barnes and Golden (1966), Hains (1973), Olin (1985), Atkins (1996), and Hedgecock and Feaster (2007). Magnitude and frequency of floods for rural streams with small drainage areas have been described by Olin and Bingham (1977) and Hedgecock (2004), and for urban streams by Olin and Bingham (1982).

\section{Description of the Study Area}

The study area includes all of Alabama, which covers an area of about 51,600 square miles $\left(\mathrm{mi}^{2}\right)$, in five physiographic provinces - Coastal Plain, Piedmont, Valley and Ridge, Appalachian Plateaus, and Interior Lowland Plateaus (fig. 1). The area north of the Fall Line, which delineates the contact of the Coastal Plain with the other provinces, has a diverse topography with land-surface elevations ranging from 200 to 2,400 feet (ft) above the North American Vertical Datum of 1988 (NAVD 88). In the Coastal Plain, elevations range from 0 to $1,000 \mathrm{ft}$ above NAVD 88 in the northwestern part of the State. The land surface generally slopes to the south and west.

Average annual precipitation ranges from about 48 inches in central and west-central Alabama to about 68 inches near the Gulf of Mexico and averages about 57 inches statewide (National Oceanic and Atmospheric Administration, 2002). Rainfall in Alabama generally is associated with the movement of warm and cold fronts across the State from November through April and isolated summer thunderstorms from May through October. Occasionally, tropical storms or hurricanes that enter the State along the gulf coast produce unusually heavy amounts of rainfall (U.S. Geological Survey, 1986). 


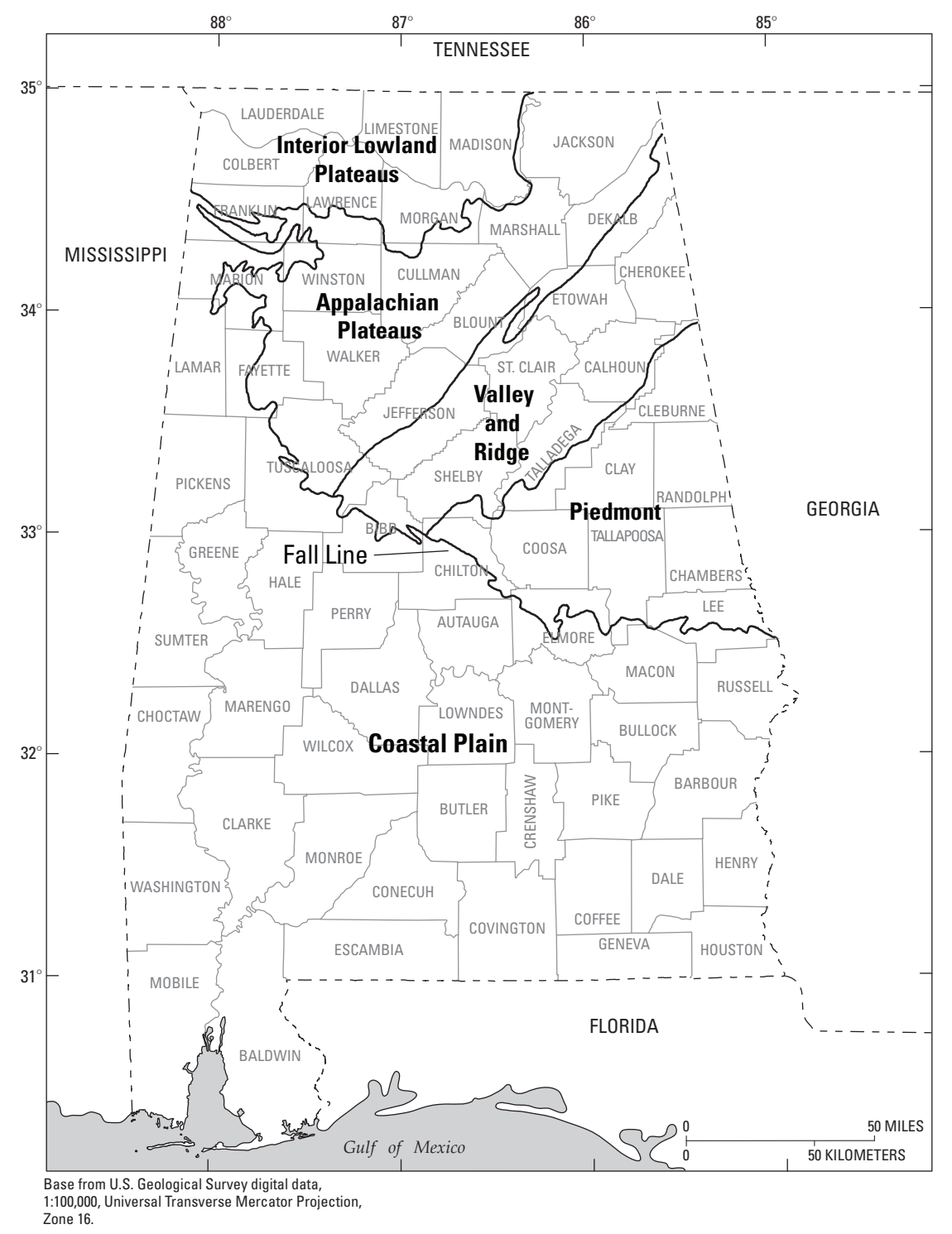

Figure 1. Locations of physiographic provinces in Alabama.

Average annual runoff varies from approximately 12 to 40 inches (National Oceanic and Atmospheric Administration, 2002). Runoff typically is greatest during February through April and least when rainfall decreases during September through November.

\section{Flood Data Used in the Analysis}

This study is based on peak-flow data collected through September 2007 at 23 urban gaging stations having 10 or more years of record. Of these 23 stations, 20 were located in Alabama, and 3 were located in the adjacent States of Florida,
Georgia, and Mississippi near the Alabama State boundary. The gaging stations in Alabama were located in or near the cities of Birmingham, Huntsville, and Mobile (figs. 2-5). Stations in adjacent States were located in Columbus, Georgia; Pensacola, Florida; and Hattiesburg, Mississippi (figs. 2, $6-8)$. The period of record for gaging stations used in this study ranged from 11 to 38 years, with an average record length of 17 years. Only gaging stations with well-defined ratings (stage-to-flow relation) were used in this study. Some gaging-station ratings were improved and extended using a one-dimensional step-backwater model (Shearman, 1990) and a culvert analysis program (Fulford, 1998). The peak-flow records used in the study were not significantly affected by 


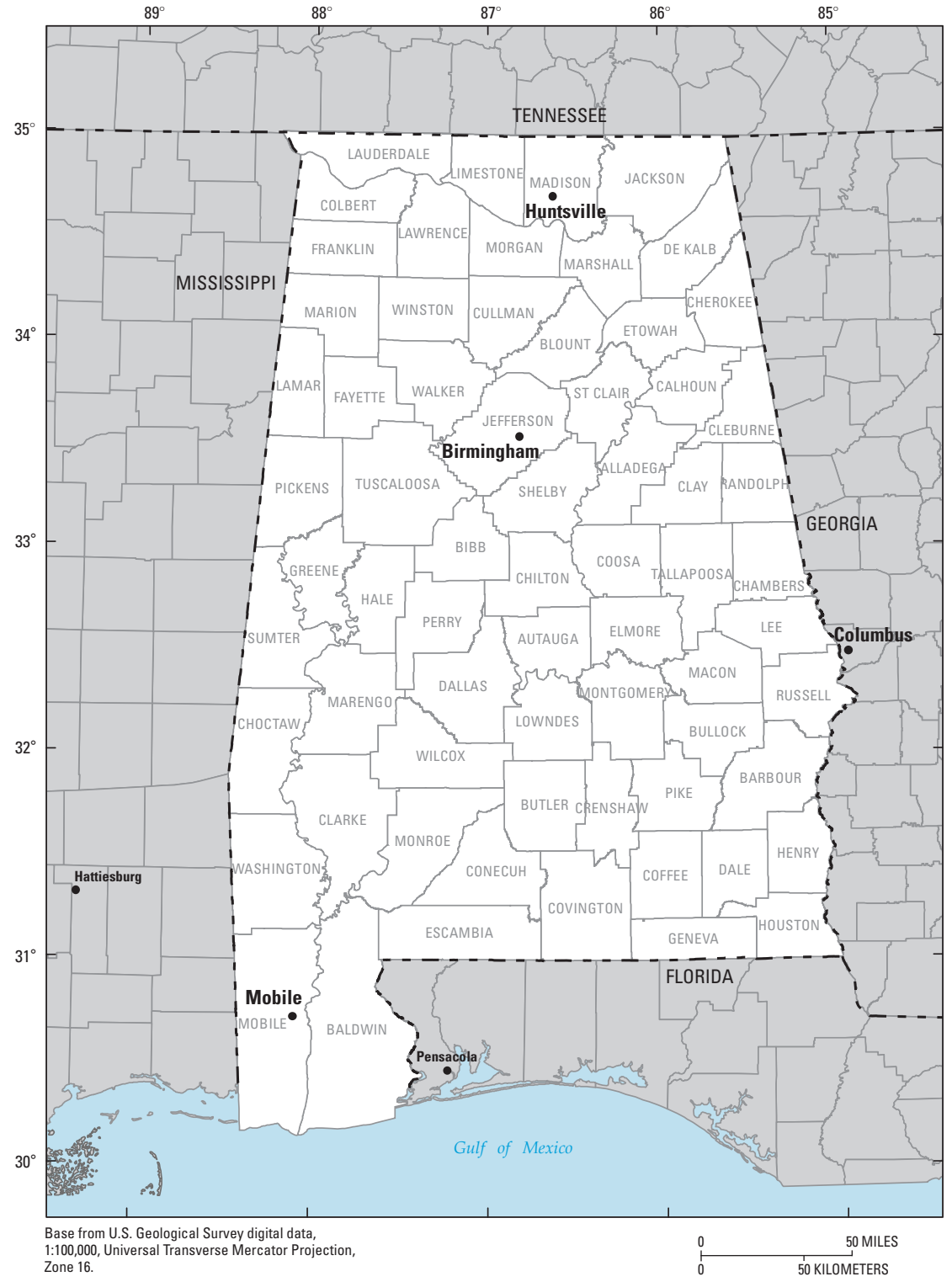

Figure 2. Locations of cities with urban streamgaging stations used in the study.

dams, flood detention structures, hurricane storm surge, or substantial tidal fluctuations. Only gaging stations located in basins having a fairly constant percentage of development for the period of gaging record were used in this study. Development could be any manmade structure, paving, or clearing of land that would increase the runoff potential in a local area. Stations having more than a 50-percent increase in development during the gaging period (Sauer and others, 1983) were not used in this study. Basin development and changes in basin development were assessed from inspection of topographical maps and aerial photographs of various vintages throughout the gaging period. Several sites located in or near Birmingham, Alabama, on Village, Valley, Fivemile, and Shades Creeks were not used in this study because of one or more of the following: (1) the existence of a substantial amount of detention storage, (2) substantial increases (greater than 50 percent) in development that occurred during the gaging period, or (3) poorly defined stage-to-flow relation for the site. 


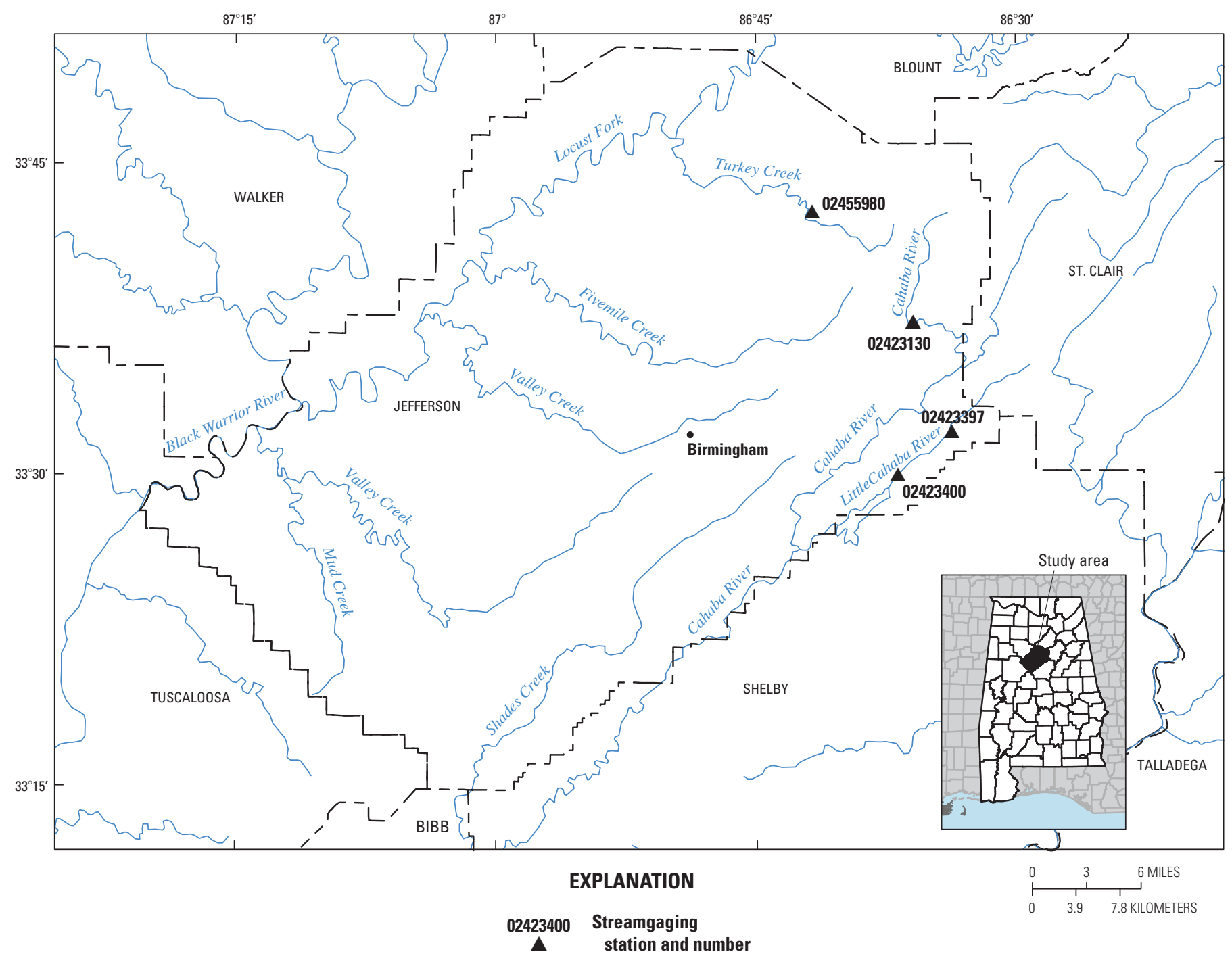

Figure 3. Locations of urban streamgaging stations in the vicinity of Birmingham, Alabama. 


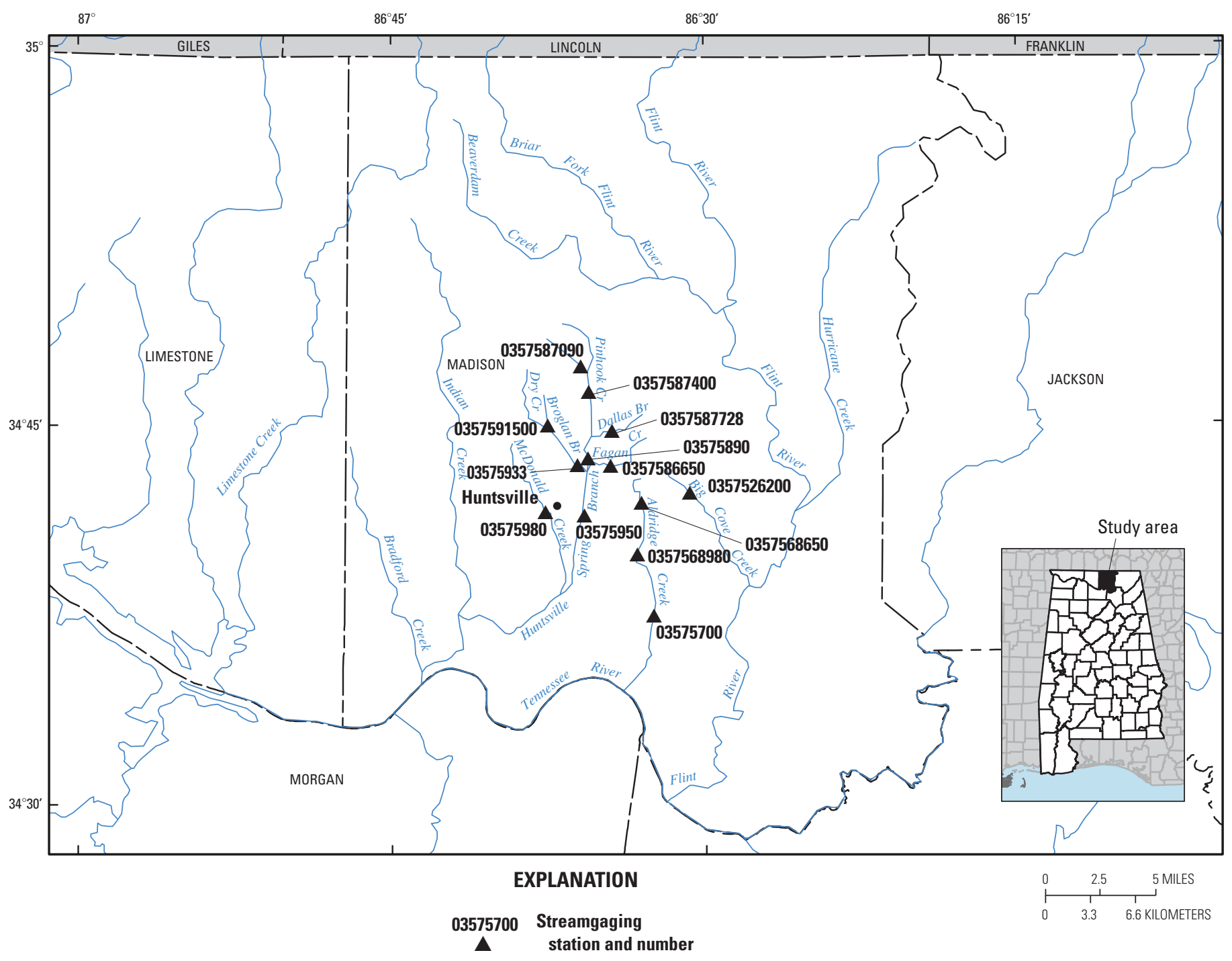

Figure 4. Locations of urban streamgaging stations in the vicinity of Huntsville, Alabama. 


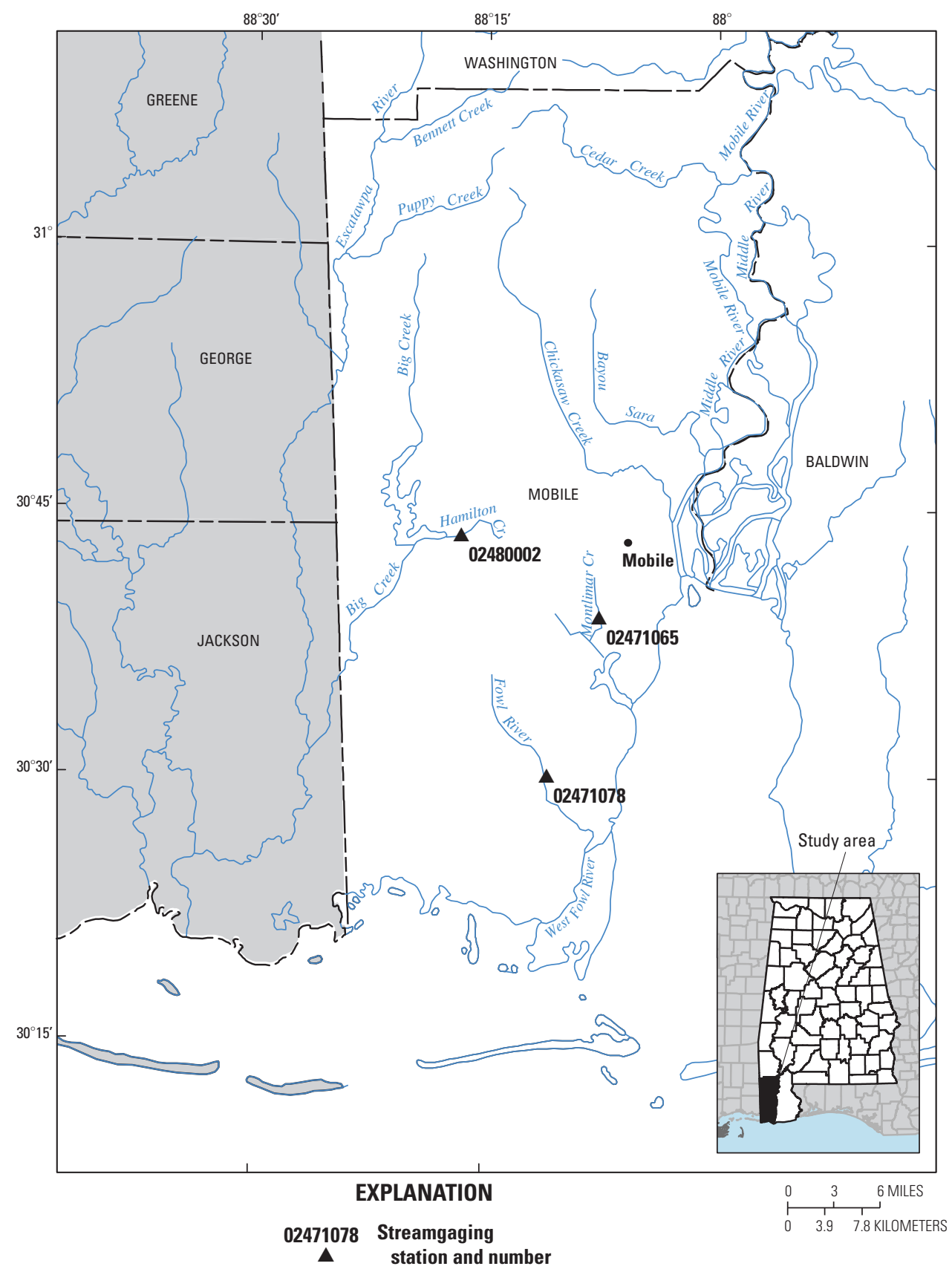

Figure 5. Locations of urban streamgaging stations in the vicinity of Mobile, Alabama. 


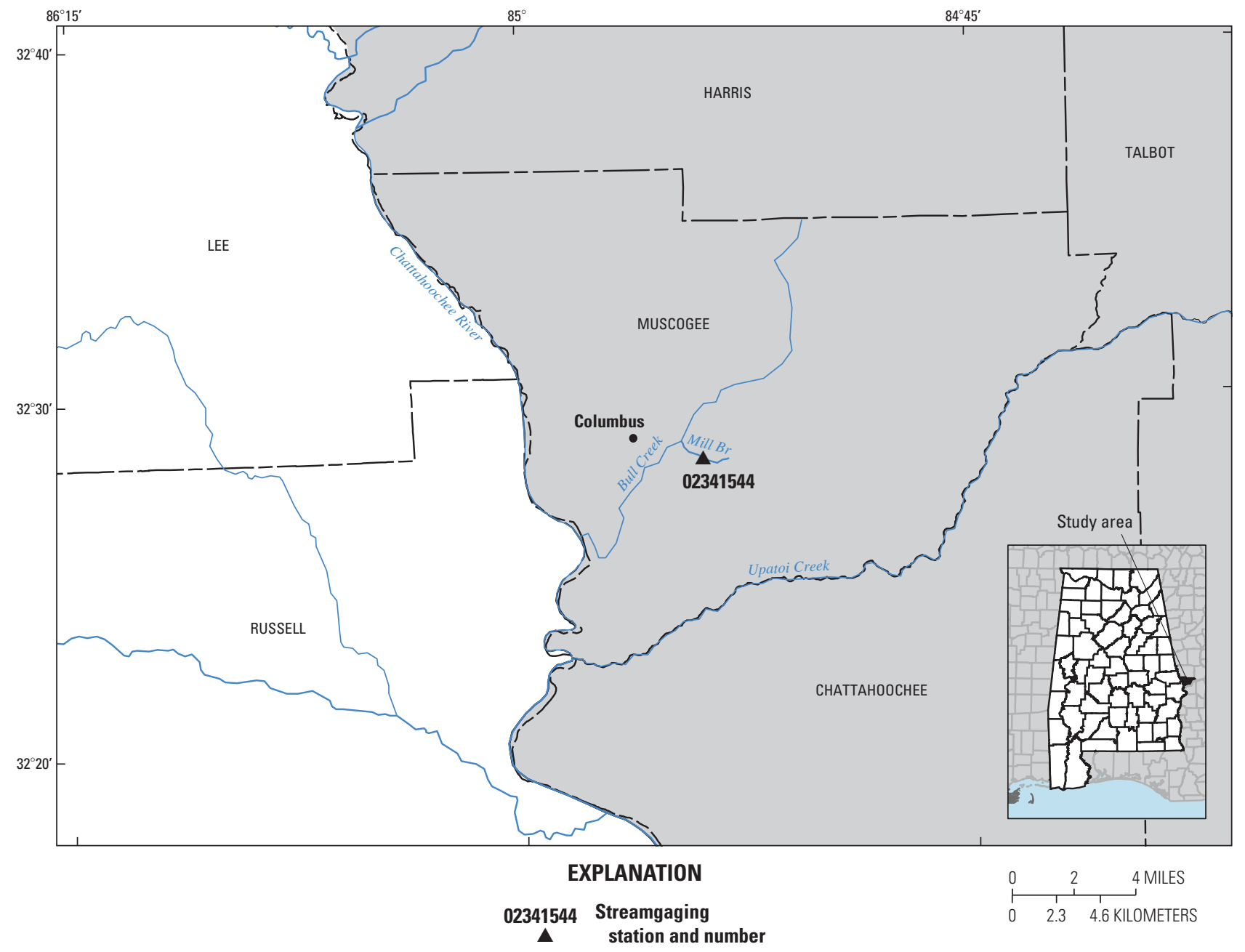

Figure 6. Location of the urban streamgaging station at Mill Branch at Columbus, Georgia. 


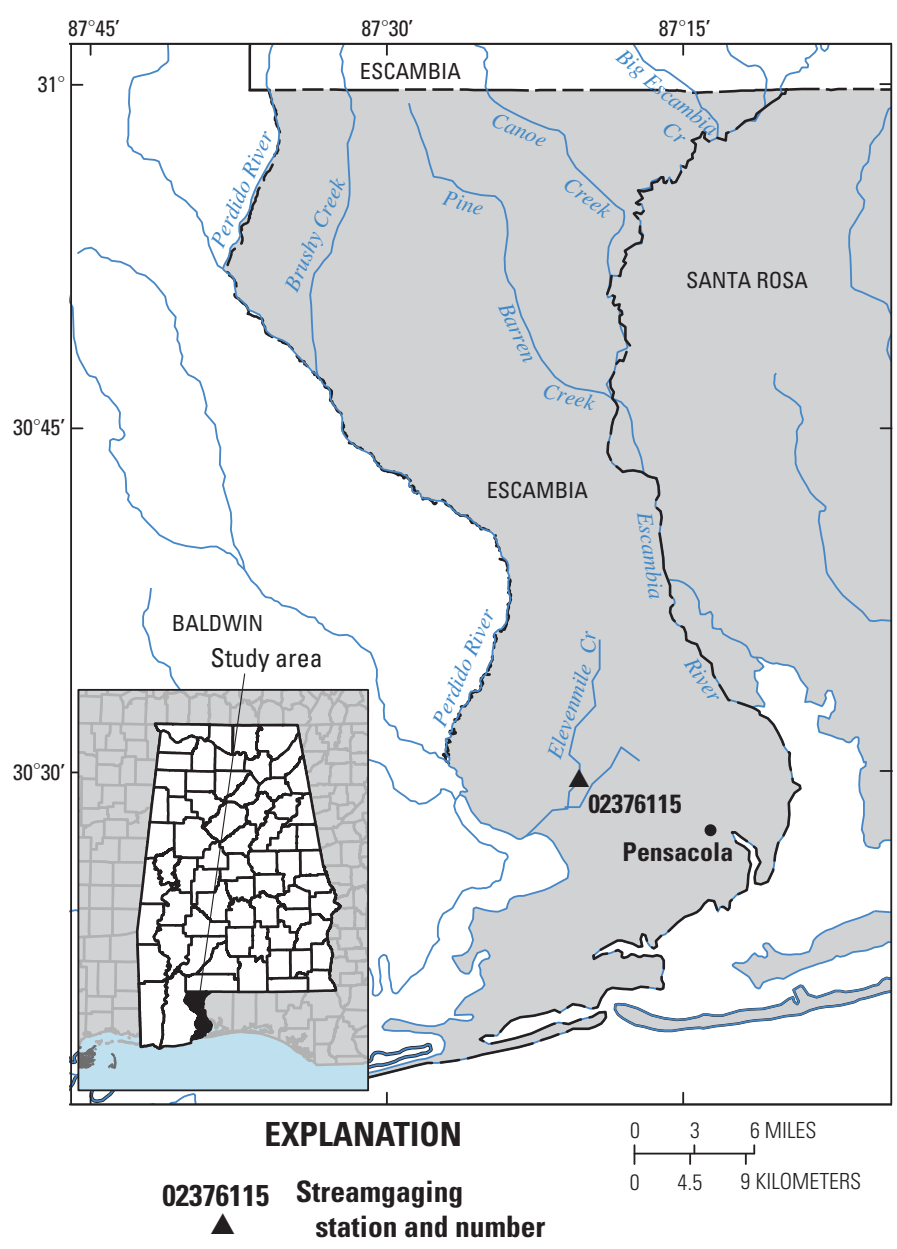

Figure 7. Location of the urban streamgaging station at Elevenmile Creek near Pensacola, Florida.

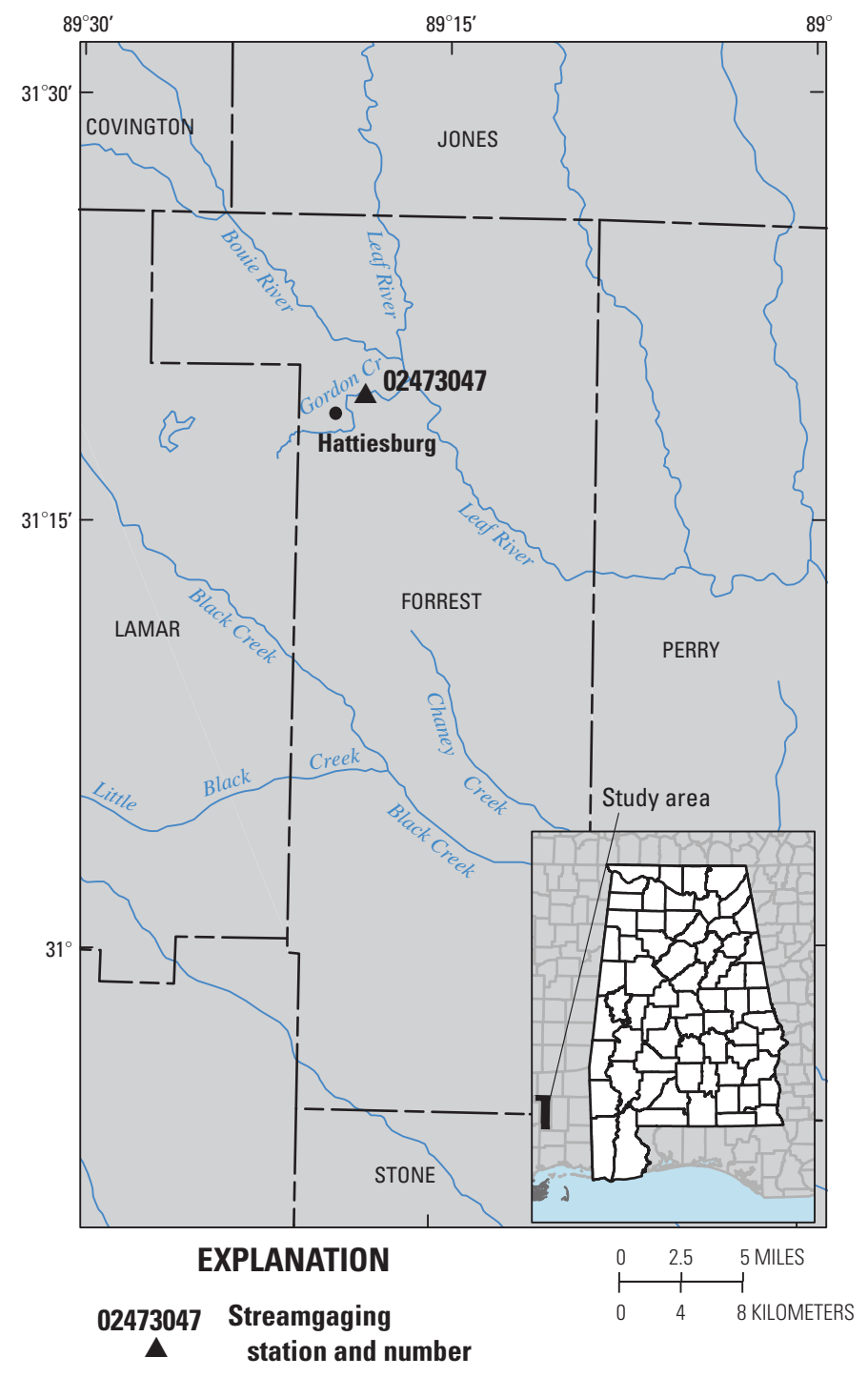

Figure 8. Location of the urban streamgaging station at Gordon Creek at Hattiesburg, Mississippi. 


\section{Flood Magnitude and Frequency at Gaging Stations}

A flood-frequency relation is the relation of peak flow to probability of exceedance. Probability of exceedance refers to the chance that a given peak flow will be exceeded in any one year. For example, a 1-percent chance exceedance flood corresponds to the flow magnitude that has a probability of 0.01 of being equaled or exceeded in any given year (table 1). A frequency analysis of annual peak-flow data at a gaging station provides an estimate of the flood magnitude and frequency at that specific stream site. Flood-frequency flows in previous USGS reports were expressed as T-year floods on the basis of the recurrence interval for that flood quantile (for example, the "100-year flood"). The use of recurrence-interval terminology is now discouraged because it sometimes causes confusion to the general public (Gotvald and others, 2009). The term is sometimes interpreted to imply that there are set time intervals between floods of a particular magnitude, when in fact floods are random processes that are best understood using probabilistic terms.

The terminology associated with flood-frequency estimates is undergoing a shift away from the T-year recurrence interval flood to the P-percent chance exceedance flood (Gotvald and others, 2009). The use of percent chance exceedance flood conveys the probability, or odds, of a flood of a given magnitude being equaled or exceeded in any given year. T-year recurrence intervals with corresponding annual exceedance probabilities and P-percent chance exceedances are given in table 1.

The flood-frequency relation for a stream having 10 or more years of streamgaging record can be defined by fitting a theoretical frequency distribution to the logarithms of

Table 1. T-year recurrence intervals with corresponding annual exceedance probabilities and P-percent chance exceedances for flood-frequency flow estimates.

\begin{tabular}{ccc}
\hline $\begin{array}{c}\text { T-year recurrence } \\
\text { interval }\end{array}$ & $\begin{array}{c}\text { Annual exceedance } \\
\text { probability }\end{array}$ & $\begin{array}{c}\text { P-percent chance } \\
\text { exceedance }\end{array}$ \\
\hline 2 & 0.50 & 50 \\
5 & 0.20 & 20 \\
10 & 0.10 & 10 \\
25 & 0.40 & 5 \\
50 & 0.02 & 2 \\
100 & 0.01 & 1 \\
200 & 0.005 & 0.5 \\
500 & 0.002 & 0.2 \\
\hline
\end{tabular}

water-year ${ }^{1}$ peak flows (largest instantaneous flow for each year). The Interagency Advisory Committee on Water Data (1982) identified fitting a Pearson Type III distribution to the logarithms of water-year peak flows as the recommended, consistent method for determining flood magnitudes and frequencies.

Commonly referred to as the log-Pearson Type III frequency analysis, this technique generally is accepted by most Federal and State agencies. Water-year peak flows for each gaging station used in this study were fitted to the log-Pearson Type III distribution (Interagency Advisory Committee on Water Data, 1982). Flood magnitudes having exceedance probabilities of $50,20,10,4,2,1,0.5$, and 0.2 percent were computed for each station by using the following equation:

$$
\log Q_{p}=M_{x}+K_{p} S_{x}
$$

where

$$
\begin{array}{cc}
Q_{p} \quad \begin{array}{l}
\text { is the P-percent chance exceedance flow, in } \\
\text { cubic feet per second; }
\end{array} \\
M_{x} \quad \begin{array}{c}
\text { is the mean of the logarithms of the water- } \\
\text { year peak flows; }
\end{array} \\
K_{p} \quad \begin{array}{l}
\text { is a Pearson Type III factor for a coefficient } \\
\text { of skewness }(G) \text { computed from the } \\
\text { logarithms of the water-year peak flows } \\
\text { and a selected probability } p \text {; and }
\end{array} \\
\begin{array}{l}
\text { is the standard deviation of the logarithms of } \\
\text { the water-year peak flows. }
\end{array}
\end{array}
$$

The flood magnitudes for gaging stations for the previously identified exceedance probabilities are listed in table 2 . Frequency estimates were not computed for urban stations located in basins having large increases in the amounts of development during the gaging period.

\section{Urban Flood-Frequency Analysis}

The flood magnitudes obtained from station frequency curves were related to basin characteristics by using generalized least squares (GLS) multiple-regression analysis. Stedinger and Tasker $(1985,1986)$ have shown that GLS regression analysis can provide more accurate estimates of regression coefficients, better estimates of the accuracy of the regression coefficients, and better estimates of the regression model error than ordinary least squares (OLS) regression analysis. OLS regression analysis does not account for the errors associated with estimates of flood magnitude varying with length of observed record, nor does it account for the cross-correlation of concurrent peak-flow data among sites. GLS regression analysis accounts for these errors by using

\footnotetext{
${ }^{1}$ Water year is the period October 1 through September 30 and is identified by the year in which the period ends. For example, the 2007 water year began on October 1, 2006, and ended at midnight on September 30, 2007.
} 


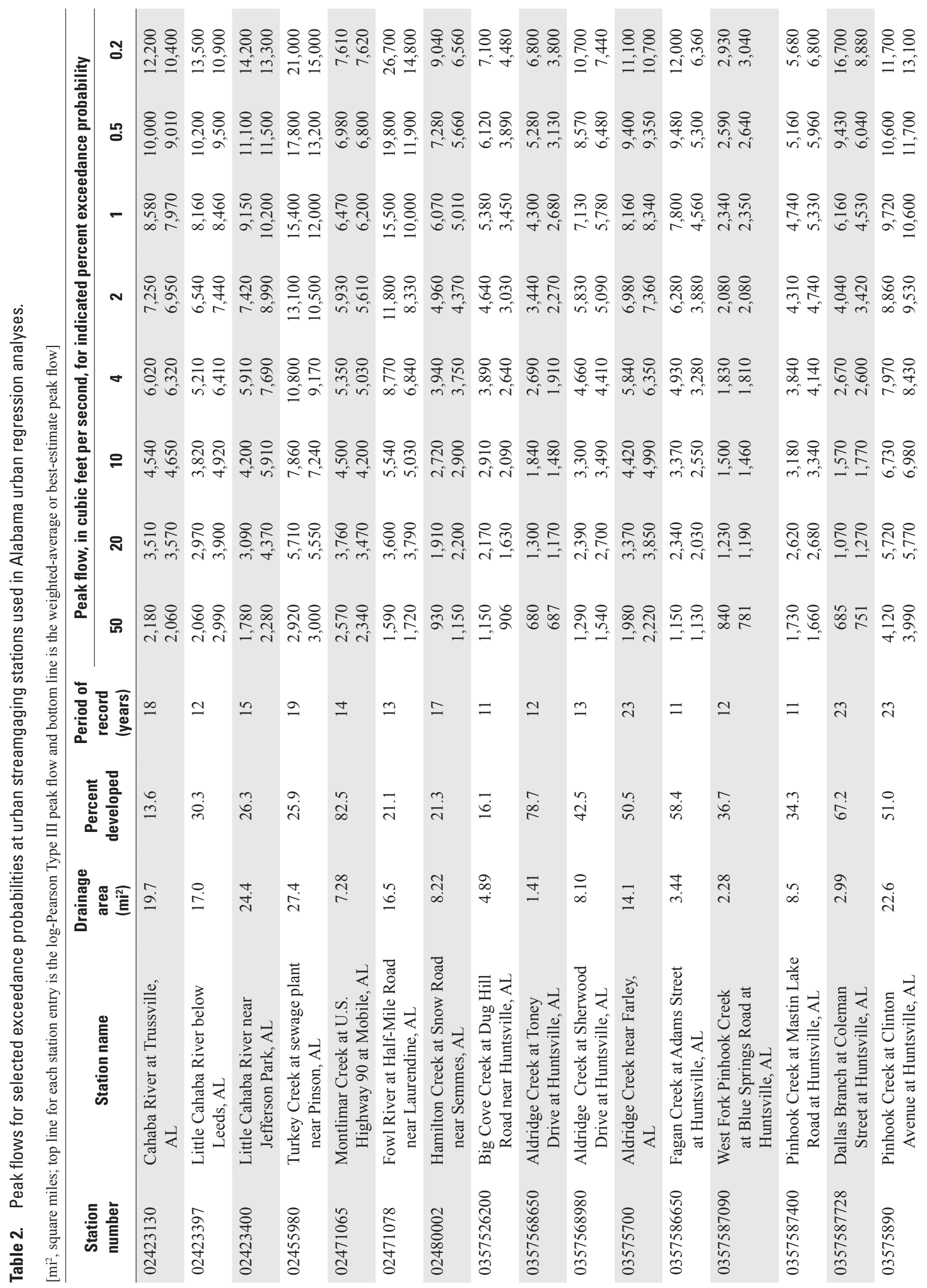




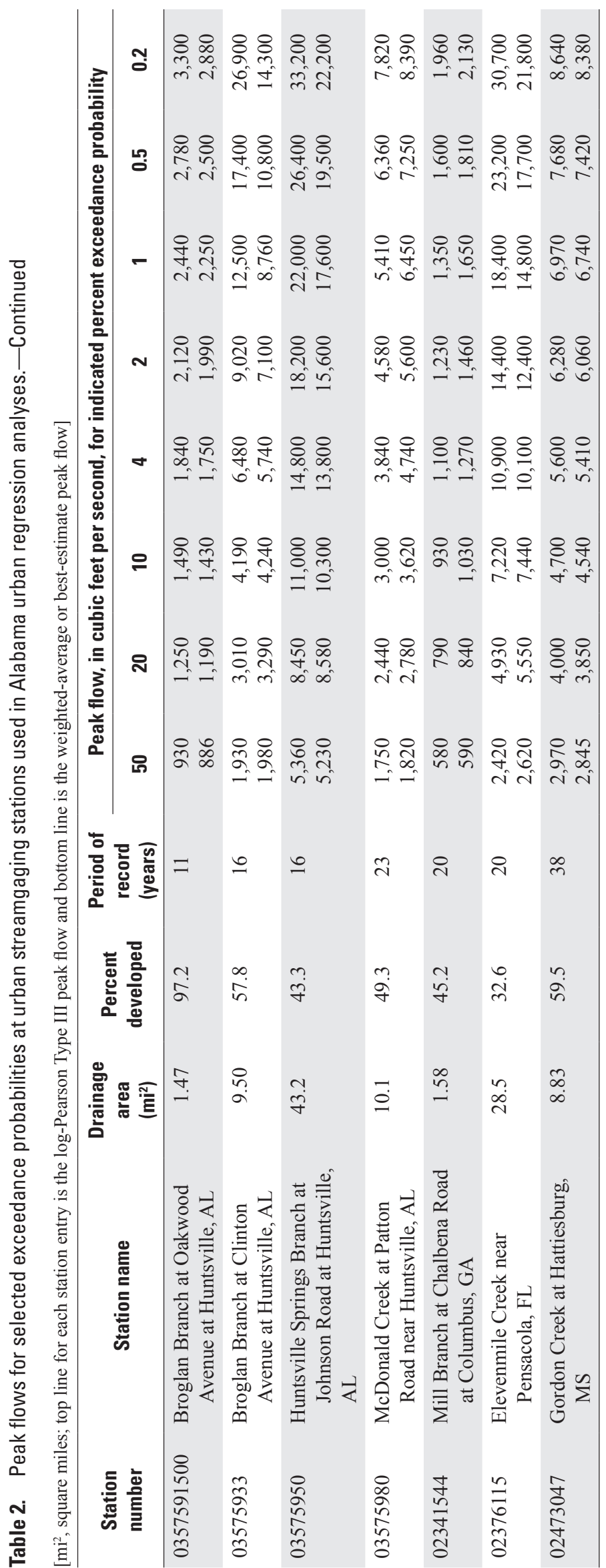


a weighting matrix so that sites are weighted proportionally according to standard errors and cross-correlation of the annual peak-flow estimates. Equations resulting from these analyses can be used to estimate flood magnitudes at ungaged sites. Basin characteristics were calculated in 2008 for each gaging station using geographic information system (GIS) coverages and distance and area measurement tools included in the Terrain Navigator Pro ${ }^{\mathrm{TM}}$ Version 8.5 software package. The following basin characteristics were tested for significance in the GLS regression analysis:

- contributing drainage area $(A)$, in square miles, upstream from the gaging station;

- main channel slope $(S)$, in feet per mile, between points 10 and 85 percent of the distance from the gaging station to the basin divide;

- main channel length $(L)$, in miles, between the gaging station and the basin divide;

- lag-time factor $(T)$, defined by the ratio $L / S^{0.5}$ with $L$ and $S$ as defined above;

- impervious area $(I A)$, in percent, percentage of the total contributing drainage area covered by impervious surfaces;

- percent developed $(P D)$, in percent, percentage of the total contributing drainage area covered by any form of development; and

- width-to-length ratio $(W / L)$, dimensionless, the average basin width to basin length. The average basin width $(W)$ is the drainage area $(A)$ divided by the main channel length $(L)$. This ratio is essentially a basin shape factor.

Exploratory multiple regression analyses were performed relating the station frequency curves to basin characteristics using OLS regression techniques. Results of the analyses indicated that contributing drainage area, main channel slope, impervious area, and percent developed were the four explanatory variables having the greatest statistical significance in relation to peak flows predicted at the streamgaging stations. Each of these basin characteristics was used in GLS regression analyses.

Initial GLS regression analyses were performed for all of the gaging stations included in the study, and multiple combinations of the four explanatory variables previously listed were used. Four different regression scenarios were explored: (1) drainage area and impervious area, (2) drainage area and percent developed, (3) scenario 1 plus main channel slope, and (4) scenario 2 plus main channel slope. These regressions were used in the development of statewide urban regression equations. Statewide urban regression equations that included drainage area and percent developed as the explanatory variables had standard errors of prediction that were lower than any of the standard errors produced from equations that included the other combinations of variables. Consequently, the statewide regression equations that included drainage area and percent developed as the explanatory variables were used as the final predictive equations for estimating urban peak flows. Analyses of these variables indicate a fairly constant influence of the drainage area term (exponent/slope not changing significantly) with increasing flood magnitude, while the percent developed term has decreasing influence with increasing flood magnitude (exponent/slope decreases significantly). The decrease of significance of the percent development at the higher flood magnitudes is expected as soils become saturated and runoff becomes more similar to that occurring in rural basins. The urban regression equations are summarized in table 3.

Table 3. Regional flood-frequency relations for urban streams in Alabama.

[Note: Associated mean standard errors of estimate, mean standard errors of prediction, and mean variance of prediction are listed in table 4. Q, flood flow, in cubic feet per second; $A$, contributing drainage area, in square miles; $P D$, percentage of basin developed]

\begin{tabular}{cc}
\hline $\begin{array}{c}\text { Exceedance } \\
\text { probability } \\
\text { (percent) }\end{array}$ & $\begin{array}{c}\text { Urban regression } \\
\text { equations }\end{array}$ \\
\hline 50 & $\mathrm{Q}=95 A^{0.648} P D^{0.407}$ \\
20 & $\mathrm{Q}=226 A^{0.670} P D^{0.298}$ \\
10 & $\mathrm{Q}=306 A^{0.675} P D^{0.276}$ \\
4 & $\mathrm{Q}=417 A^{0.670} P D^{0.253}$ \\
2 & $\mathrm{Q}=513 A^{0.663} P D^{0.237}$ \\
1 & $\mathrm{Q}=618 A^{0.656} P D^{0.223}$ \\
0.5 & $\mathrm{Q}=733 A^{0.650} P D^{0.210}$ \\
0.2 & $\mathrm{Q}=897 A^{0.642} P D^{0.196}$ \\
\hline
\end{tabular}

\section{Accuracy and Limitations of Flood-Frequency Estimates}

The accuracy of a flood-frequency relation traditionally has been expressed in two ways - the mean standard error of estimate $\left(S E_{E}\right)$ or as mean standard error of prediction $\left(S E_{P}\right)$. The $S E_{E}$ is a measure of how well the regression equation fits the data used to derive the relation and is often referred to as the model error. The $S E_{E}$ is the standard deviation of the differences between station data and the corresponding values computed from the regression equation. The $S E_{E}$ ranged from a minimum of 17 percent (10-percent exceedance flood) to a maximum of 31 percent (0.2-percent exceedance flood; table 4). The $S E_{P}$ is a measure of how well the regression relation estimates flood magnitudes when applied to ungaged basins. The $S E_{p}$ is the square root of the mean square error of prediction, $\stackrel{p}{M S E_{p}}$. The $M S E_{p}$ is the sum of two components - the mean square error resulting from the model and 
Table 4. Accuracy of regional flood-frequency relations for urban streams in Alabama.

\begin{tabular}{cccc}
\hline $\begin{array}{c}\text { Exceedance } \\
\text { probability } \\
\text { (percent) }\end{array}$ & $\begin{array}{c}\text { Mean } \\
\text { standard } \\
\text { error of } \\
\text { estimate } \\
\text { (percent) }\end{array}$ & $\begin{array}{c}\text { Mean } \\
\text { standard } \\
\text { error of } \\
\text { prediction } \\
\text { (percent) }\end{array}$ & $\begin{array}{c}\text { Mean } \\
\text { variance of } \\
\text { prediction } \\
\text { (log units) }\end{array}$ \\
\hline 50 & 22 & 26 & 0.0120 \\
20 & 18 & 21 & 0.0085 \\
10 & 17 & 21 & 0.0082 \\
4 & 19 & 24 & 0.0102 \\
2 & 21 & 26 & 0.0128 \\
1 & 24 & 30 & 0.0160 \\
0.5 & 27 & 33 & 0.0197 \\
0.2 & 31 & 38 & 0.0254 \\
\hline
\end{tabular}

\section{Use of Flood-Frequency Relations}

Regional flood-frequency equations or relations can be used to estimate flood magnitudes at ungaged sites or to improve estimates at gaged sites. Methods are presented in the following section that describe procedures for use in obtaining these estimates.

\section{Gaged Sites}

Flood estimates at gaged sites for a selected exceedance probability can be determined best by weighting the regional and station flood estimates for the specified exceedance probability using the variance of prediction for each of the two estimates. The variance of prediction can be thought of as a measure of the uncertainty in either the gaging-station flow estimate or the regional regression results. If the two estimates the sampling mean square error, which results from estimating the model parameters from samples of the population. The $S E_{p}$ ranged from a minimum of 21 percent (20- and 10-percent exceedance floods) to a maximum of 38 percent (0.2-percent exceedance flood). Another measure of the uncertainty in a regression equation estimate for a site is the variance of prediction, $V_{p}$. The $V_{p}$ is the sum of the model error variance and sampling error variance. The mean variance of prediction, $M V P$, can be computed for $n$ number of stations to determine the average accuracy of prediction, assuming that the explanatory variables for the gaging stations in a regression analysis are representative of all stations in the region. The $S E_{E}, S E_{p}$, and $M V P$ for the regression relations are listed in table 4.

The regression relations are applicable for ungaged urban basins having drainage areas ranging from 1 to $43 \mathrm{mi}^{2}$ and basin development ranging from 20 to 100 percent. The equations should not be used for basins having less than 20-percent development or where dams, flood-detention structures, hurricane storm surge, or substantial tidal fluctuations have a significant effect on peak flows. Sites in basins having less than 20-percent development should be considered as rural sites. The user is cautioned not to use the urban equations for streams located in flood region 3 (fig. 9). Flood region 3 has impervious chalk and marl, which produce high flood runoff. No stations in flood region 3 were used to develop the urban equations; therefore, flood region 3 rural equations (Hedgecock and Feaster, 2007) should be used for urban sites located in this region.

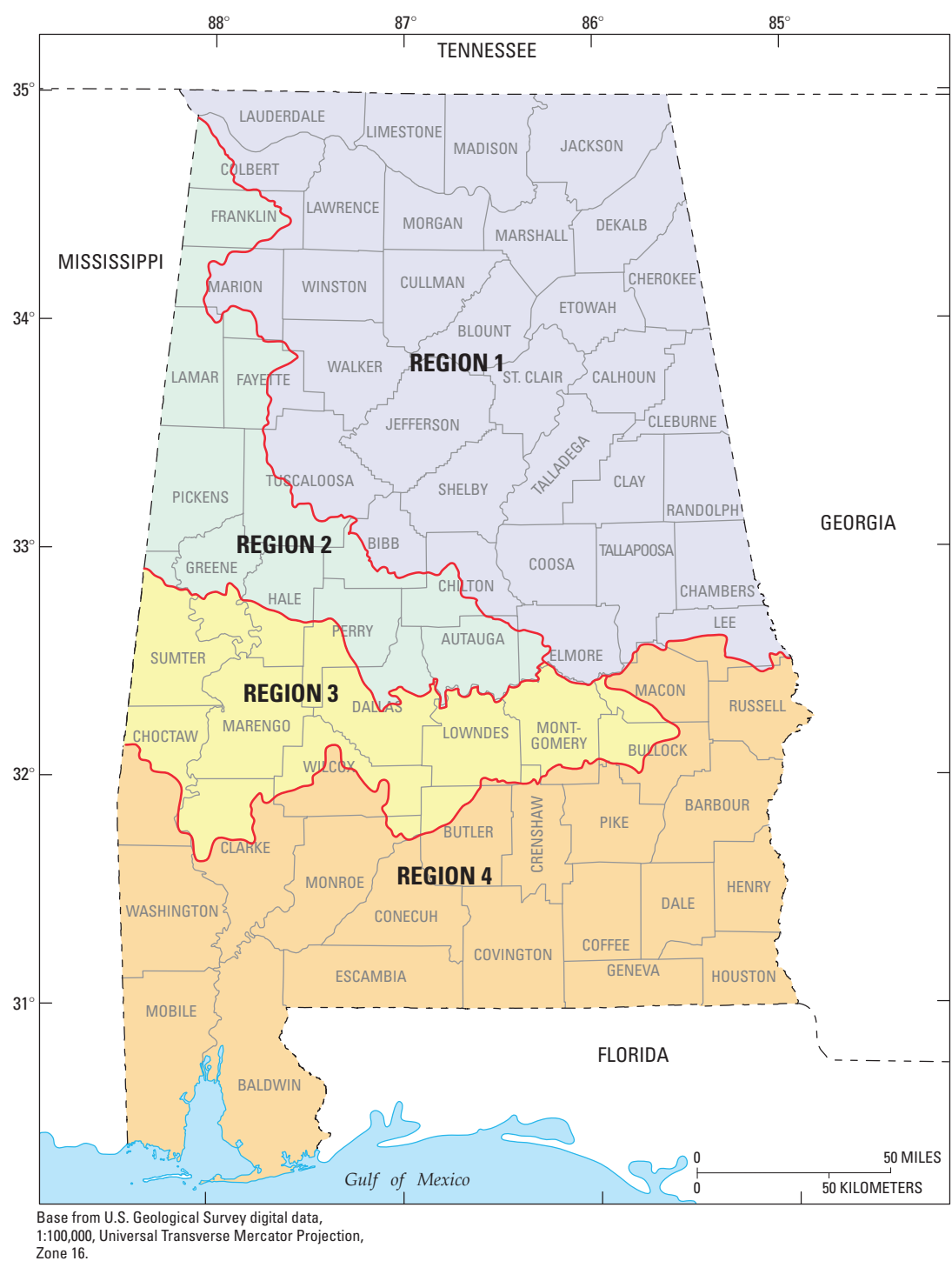

Figure 9. Locations of the four flood regions in Alabama. 
can be assumed to be independent and are weighted in inverse proportion to the associated variances, the variance of the weighted estimate will be less than the variance of either of the independent estimates.

The variance of prediction corresponding to the gagingstation flow estimate from the log-Pearson Type III analysis is computed using the asymptotic formula given in Cohn and others (2001) with the addition of the mean-squared error of generalized skew (Griffis and others, 2004). This variance varies as a function of the length of record and the fitted log-Pearson Type III distribution parameters (mean, standard deviation, and station skew). The variance of prediction values for the gaging-station flow estimates for the 23 gaging stations used in urban regression analyses are shown in table 5 . The variance of prediction from the regression equations is a function of the regression equations and the values of the independent variables used to develop the flow estimate from the regression equations. Once the variances have been computed, the two independent flow estimates can be weighted using the following equation:

$$
\log Q_{P(g) w}=\frac{V_{p, P(g) r} \log Q_{P(g) s}+V_{p, P(g) s} \log Q_{P(g) r}}{V_{p, P(g) s}+V_{p, P(g) r}},
$$

where

$$
\begin{aligned}
& Q_{P(g) w} \quad \text { is the weighted estimate of peak flow for any } \\
& \text { P-percent chance exceedance for a gaged } \\
& \text { station, in cubic feet per second; } \\
& V_{p, P(g) r} \quad \text { is the variance of prediction at the gaged } \\
& \text { station derived from the regression } \\
& \text { equation for the selected P-percent chance } \\
& \text { exceedance (from table 4), in log units; } \\
& Q_{P(g) s} \quad \text { is the estimate of peak flow at the gaged } \\
& \text { station from the log-Pearson Type III } \\
& \text { analysis for the selected P-percent chance } \\
& \text { exceedance, in cubic feet per second; } \\
& V_{p, P(g)_{s}} \quad \text { is the variance of prediction at the gaged } \\
& \text { station from the log-Pearson Type III } \\
& \text { analysis for the selected P-percent chance } \\
& \text { exceedance (from table 5), in log units; and } \\
& Q_{P(g) r} \quad \text { is the peak-flow estimate for the P-percent } \\
& \text { chance exceedance at the gaged station } \\
& \text { derived from the applicable regression } \\
& \text { equation (from table } 3 \text { ), in cubic feet } \\
& \text { per second. }
\end{aligned}
$$

When the variance of prediction corresponding to one of the estimates is high, the uncertainty also is high, so the weight for that estimate is relatively small. Conversely, when the variance of prediction is low, the uncertainty also is low, so the weight is correspondingly large. The variance of prediction associated with the weighted estimate, $V_{p, P(g) w}$, is computed using the following equation:

$$
V_{p, P(g) w}=\frac{V_{p, P(g) s} V_{p, P(g) r}}{V_{p, P(g) s}+V_{p, P(g) r}},
$$

where variables are as previously defined.

Flood magnitudes obtained from station frequency curves were weighted using equation 2 and the variance of prediction values from tables 4 and 5 . The weighted values (best estimate) shown in table 2 for each of the 23 stations are for design purposes at gaged sites. The variance of prediction values associated with the weighted estimates are shown in table 5 .

\section{Comparison of Results with Previous Alabama Study Results}

Equations were developed for urban streams in Alabama (Olin and Bingham, 1982) using multiple regression analyses of flood magnitudes obtained from synthetic flow data generated with a calibrated rainfall-runoff model and basin characteristics for 23 urban gaging stations. The regression analyses indicated that drainage area size and percentage of the basin occupied by impervious materials were the most significant basin characteristics affecting flood frequency and magnitude of urban streams.

The results of this study indicate that a different combination of two explanatory variables best correlate to flood peaks that occur on urban streams today. Drainage area and percent developed provided the best correlation for the data used in the analysis. Both the 1982 and 2009 equations were applied to the current dataset (drainage area and associated impervious area or percent developed) used for this study. Results indicate that the 2009 equations predict higher peak flows than the 1982 equations for 21 out of 23 stations (1-percent exceedance flow). For these 21 stations, the average increase in the predicted peak flow was about 18 percent. For the two stations having a lower predicted peak flow, the average reduction of flow was about 3 percent (1-percent exceedance flow).

A second comparison was made for hypothetical sites having drainage areas of $1,5,10,25$, and $40 \mathrm{mi}^{2}$. For each of these drainage areas, values of 20-, 40-, 60-, 80-, and 99-percent developed were applied to both the 1982 and 2009 equations. Because the explanatory variables are not the same, a direct comparison could not be made. Regression techniques were used to relate impervious area to percent developed using the current dataset. Results of these regressions indicate that percent developed correlates to about 3.75 times the computed impervious area. Using this factor, an approximate comparison was made between the 1982 and 2009 equations.

Experimentation with the 1982 and 2009 urban equations has generally shown that higher peak flows are predicted by the 2009 equations for sites having drainage areas less than $25 \mathrm{mi}^{2}$ and impervious areas less than 25 percent (94-percent developed). This was true for the 50-percent to 


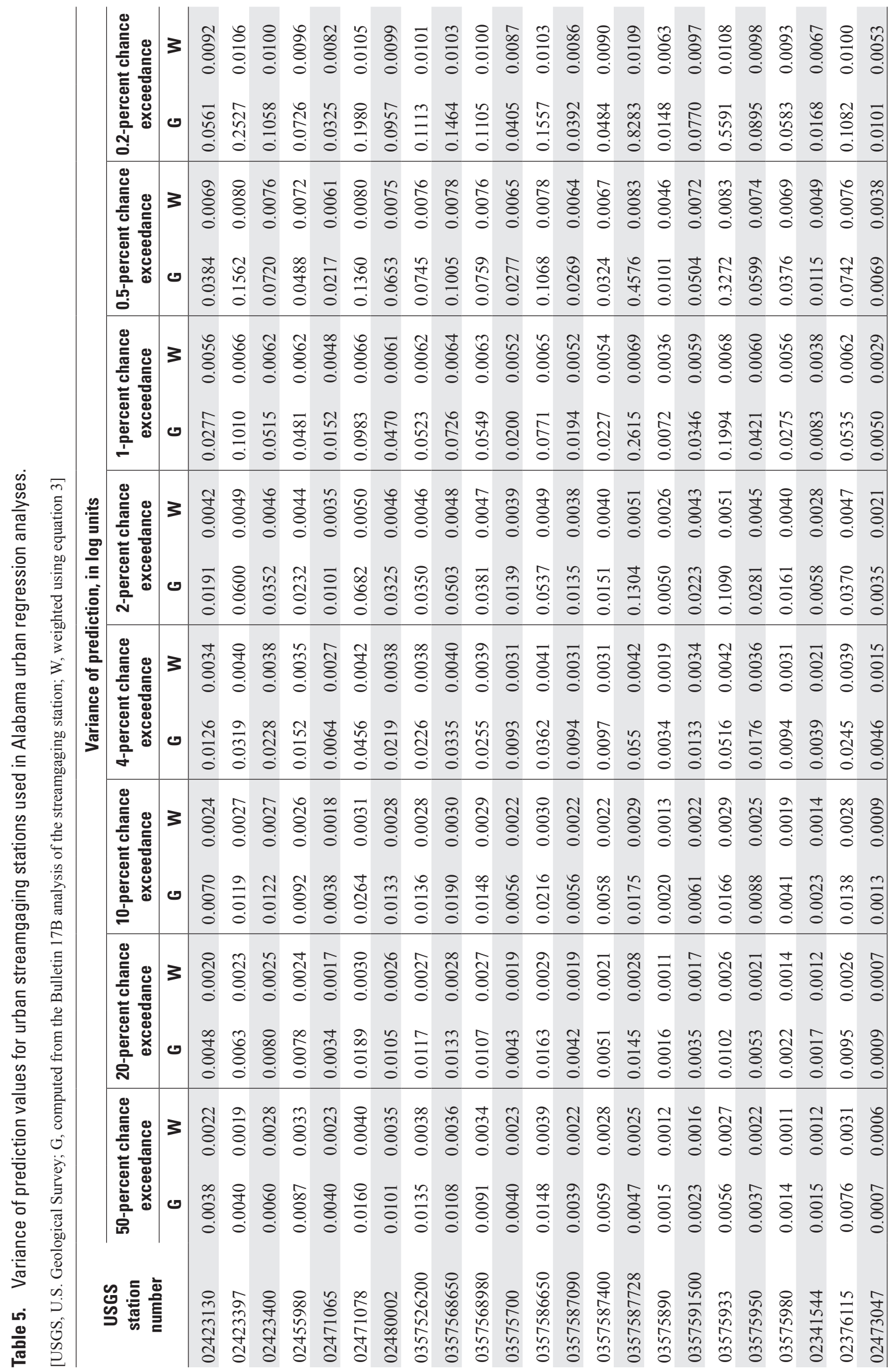


1-percent exceedance probabilities. For larger sites (up to $43 \mathrm{mi}^{2}$ ) that have impervious areas greater than 25 percent (94-percent developed), the 1982 equations typically predict slightly higher flows (for 50-percent to 1-percent exceedance probabilities).

\section{Summary}

Flood flows for selected exceedance probabilities of $50,20,10,4,2,1,0.5$, and 0.2 percent were determined for 20 streamgaging stations on urban streams in Alabama using the log-Pearson Type III frequency distribution. The data for these sites in Alabama and three additional stations in parts of the adjacent States of Florida, Georgia, and Mississippi were used to develop flood-frequency relations that can be used to estimate flood flows for exceedance probabilities of 50, 20, 10, $4,2,1,0.5$, and 0.2 percent for ungaged, unregulated urban streams in Alabama.

Multiple-regression techniques were used to develop predictive equations relating peak flow to one or more drainage-basin characteristics. Contributing drainage area, main channel slope, impervious area, and percent developed were the four explanatory variables having the greatest statistical significance in relation to peak flows predicted at the streamflow-gaging stations. Each of these basin characteristics was used in generalized least squares regression analyses. Drainage area and percent developed were determined to be the most significant variables for use in predicting flood flows for urban streams in Alabama. Generalized least-squares regression methods were used to define the final regression coefficients used in the predictive equations and the model and prediction errors.

The flood-frequency relations can be applied to streams in Alabama whose flood-peak flows are not significantly affected by dams, flood detention structures, hurricane storm surge, or substantial tidal fluctuations. These regression relations are applicable for ungaged urban basins having drainage areas ranging from 1 to $43 \mathrm{mi}^{2}$ and basin development ranging from 20 to 100 percent. Methods are presented in the report for determining flood flows for selected exceedance probabilities on ungaged and gaged streams.

\section{References}

Atkins, J.B., 1996, Magnitude and frequency of floods in Alabama: U.S. Geological Survey Water-Resources Investigations Report 95-4199, 234 p.

Barnes, H.H., Jr., and Golden, H.G., 1966, Magnitude and frequency of floods in the United States, Part 2-B, South Atlantic slope and eastern Gulf of Mexico basins, Ogeechee River to Pearl River: U.S. Geological Survey Water-Supply Paper 1674, 409 p.
Cohn, T.A., Lane, W.L., and Stedinger, J.R., 2001, Confidence intervals for Expected Moments Algorithm flood quantile estimates: Water Resources Research, v. 37, no. 6, p. 1695-1706.

Fulford, J.M., 1998, User's guide to the U.S. Geological Survey Culvert Analysis Program, version 97-08: U.S. Geological Survey Water-Resources Investigations Report 98-4166, 68 p.

Gamble, C.R., 1965, Magnitude and frequency of floods in Alabama: Alabama Highway Department HPR Report No. 5, 42 p.

Gotvald, A.J., Feaster, T.D., and Weaver, J.C., 2009, Magnitude and frequency of rural floods in the southeastern United States, 2006-Volume 1, Georgia: U.S. Geological Survey Scientific Investigations Report 2009-5043, 120 p.

Griffis, V.W., Stedinger, J.R., and Cohn, T.A., 2004, Log Pearson type 3 quantile estimators with regional skew information and low outlier adjustments: Water Resources Research, v. 40, W07503, doi:10.1029/2003WR002697.

Hains, C.F., 1973, Floods in Alabama, magnitude and frequency: Alabama Highway Department Special Report, $174 \mathrm{p}$.

Hedgecock, T.S., 2004, Magnitude and frequency of floods on small rural streams in Alabama: U.S. Geological Survey Scientific Investigations Report 2004-5135, 10 p.

Hedgecock, T.S., and Feaster, T.D., 2007, Magnitude and frequency of floods in Alabama, 2003: U.S. Geological Survey Scientific Investigations Report 2007-5204, 28 p., + app.

Interagency Advisory Committee on Water Data, 1982, Guidelines for determining flood-flow frequency: Bulletin 17B, $183 \mathrm{p}$.

National Oceanic and Atmospheric Administration, 2002, Monthly station normals of temperature, precipitation, and heating and cooling degree days 1971-2000: National Environmental Satellite, Data, and Information Service; National Climatic Data Center, Climatography of the United States No. 81, 26 p. (available online at http://nsstc.uah.edu/aosc/ files/ALnorm.pdf).

Olin, D.A., 1985, Magnitude and frequency of floods in Alabama: U.S. Geological Survey Water-Resources Investigations Report 84-4191, 105 p., 1 pl.

Olin, D.A., and Bingham, R.H., 1977, Flood frequency of small streams in Alabama: Alabama Highway Department, HPR Report No. 83, 44 p.

Olin, D.A., and Bingham, R.H., 1982, Synthesized flood frequency of urban streams in Alabama: U.S. Geological Survey Water-Resources Investigations Report 82-683, 35 p. 
Pierce, L.B., 1954, Floods in Alabama, magnitude and frequency: U.S. Geological Survey Circular 342, 105 p.

Sauer, V.B., Thomas, W.O., Stricker, V.A., and Wilson, K.V., 1983, Flood characteristics of urban watersheds in the United States: U.S. Geological Survey Water-Supply Paper 2207, 63 p.

Shearman, J.O., 1990, User's manual for WSPRO-A computer model for water surface profile computation: U.S. Department of Transportation, no. FHWA-IP-89-027, $177 \mathrm{p}$.

Speer, P.R., and Gamble, C.R., 1964, Magnitude and frequency of floods in the United States, Part 3-B, Cumberland and Tennessee River basins: U.S. Geological Survey Water-Supply Paper 1676, 340 p.
Stedinger, J.R., and Tasker, G.D., 1985, Regional hydrologic analysis 1 . Ordinary, weighted and generalized least squares compared: Water Resources Research, v. 21, no. 9, p. 1421-1432.

Stedinger, J.R., and Tasker, G.D., 1986, Correction to "Regional hydrologic analysis 1 . Ordinary, weighted and generalized least squares compared": Water Resources Research, v. 22, no. 5, p. 844.

U.S. Geological Survey, 1986, National water summary 1985-Hydrologic events and surface-water resources: U.S. Geological Survey Water-Supply Paper 2300, 506 p. 

